\title{
PAPER
}

\section{Teaching on Religion and Violence}

Charles K. Bellinger

Texas Christian University

\begin{abstract}
I have many times now taught a course entitled "Religion and Violence" at Brite Divinity School and Texas Christian University. The Brite course is in-class; the TCU course is online with Master of Liberal Arts students. I will describe the difference between the two formats and also provide sample syllabi. The course has traditionally focused on the "why" question-“Why are human beings violent?"rather than on ethical debates about pacifism vs. just war. Feedback from the online students often asked for another course focusing on peacemaking, now that the psychology of violence has become better understood. I therefore developed a new course called "Peacemaking in a Violent World," which will also be described. I will make the argument that our culture as a whole would benefit from greater curricular attention to the psychology of violence, at all levels of education. I will also provide attendees with a bibliography for collection development in this area.
\end{abstract}

A brief aside first about the title. In email correspondence with Wolfgang Palaver, a professor in Europe with interests similar to mine, he indicated that he teaches a course called "Violence and Religion." He 
prefers that ordering of the words because "Religion and Violence" subtly implies that religion is a causative agent and violence is the outflow of that cause. I agree with him on this point; he and I both stress that violence is a phenomenon that needs to be understood on its own, without the a priori assumption that religion is somehow its cause. But it is too late for me to go back and change the title that I have given to the course in the past.

I need to begin with an account of how I became interested in this topic. In college, I became interested in the ethical questions surrounding pacifism and the just war theory. Then I read a book called Escape from Evil by Ernest Becker; this book opened up to me the question of why human beings are violent. Becker answered that question by pointing to the fear of death. At first I found his answer convincing, but as I continued to read various books in psychology, sociology, philosophy, and theology, I gradually became disenchanted with Becker and sought other guides. Eventually two authors rose to the top of my estimation, Søren Kierkegaard and René Girard. I later wrote my dissertation on them.

During my first master's degree program, I took a course called "Religion and Violence" from Mark Juergensmeyer; this was when he was teaching at University of California, Berkeley. Violence and the Sacred by Girard was one of the books assigned by Juergensmeyer; this was my first exposure to Girard. I did not fully understand the book and Girard's significance, but when Girard himself came and gave a guest lecture in Berkeley, I gained a better picture of his mimetic theory and its relation to the Bible, and I went on to read his other books. Juergensmeyer, as many of you no doubt know, has continued to be a major voice regarding the topic at hand, through books such as Terror in the Mind of God, and I have assigned that book quite often in the past. But in my judgment, Juergensmeyer's theory of violence is not very deep. His observations tend to remain at a journalistic level; he too readily takes the words of terrorists or their supporters at face value, and searches for "motives" within those words. I have come to the conclusion that the better-quality books on violence always have as their unspoken epigraph "They know not what they do." What is needed is a kind of depth psychology or depth theological anthropology that understands the motives of those who are violent better than they understand themselves. 
I have been teaching at Brite Divinity School since 2000, and I have taught a course called "Religion and Violence" many times. My approach has usually been to focus more on the "why" question of violence than on the ethical debates about war and how to respond to terrorism, though those topics do come up. I typically expose the students to various theories about the roots of violence in human behavior, which have been articulated by Ernest Becker, Carl Jung, Alice Miller, Kenneth Burke, Mark Juergensmeyer, and others. I also usually summarize the critiques of religion presented by the so-called angry atheists such as Sam Harris and Richard Dawkins, though their perspectives are not very philosophically substantial. I present the theories of Kierkegaard and Girard as those which I find to be the most thought-provoking and insightful. Kierkegaard focuses on the idea that human beings are psychologically and spiritually immature, and our violence arises out of our rejection of God's call to us to become more mature, which entails truly seeing and loving all other human beings as our neighbor. Girard focuses on the idea that we copy the desires of other people around us, which creates a situation of rivalry, envy, conflict, and potential violence. Society prevents itself from suffering a breakdown into chaotic violence by channeling its violent impulses toward a scapegoat, which could be an individual or a minority group within society. Mimetic desire leads to the scapegoat mechanism, and the Bible reveals both of those basic cultural dynamics clearly; that is Girard's theory in a nutshell. (I would like to note, as an aside, that the phrase "the scapegoat mechanism" was not coined by Girard; Kenneth Burke was using that phrase in the 1930s, and we know that Girard read Burke because he comments on him.)

In my most recent iteration of this course, which was just this past spring semester, one of my students offered an intriguing reading of Girard. One of the key phrases in Girard is acquisitive mimesis, our desire to have what others have; but my student suggested that it is not just acquisitiveness that can be imitated, but also fear. This is a thought-provoking idea that applies well to various historical contexts including our own. Politicians and other rhetors often seek to sway crowds in the direction of scapegoating and violence by whipping up fears of alleged internal or external enemies. Adolf Hitler was obviously a master of this.

In general, I have found that the students have responded well to 
Girard's thought; they find his ideas not only philosophically insightful but also useful in terms of homiletics and pastoral care. While I consider Kierkegaard to be a more subtle and complex thinker than Girard, his writings are more philosophically challenging to grasp. Assigning The Sickness unto Death, as I did in the latest iteration of the course, was probably a mistake, because the level at which it is written is more appropriate for doctoral-level students than first master's students. In the past, I assigned a summary of Kierkegaard written by myself and selected excerpts from his writings. In terms of Girard, I have assigned both The Girard Reader and I See Satan Fall Like Lightning in various semesters. I have decided that I See Satan Fall is the better choice pedagogically because it is more accessible and provides a better overall introduction to his thought.

Eric Voegelin is another key thinker I draw on. He was a political philosopher and historian in the twentieth century. He articulated what I call dimensional anthropology, which is the idea that there are three main dimensions of reality as it is inhabited by human beings. First, there is the vertical axis of God and nature, or the spiritual and the material. This has traditionally been called the Great Chain of Being. The second main dimension is the horizontal plane, which means human social existence: culture, community, the nationstate, the family, and so forth. The third dimension is individual selfhood. Voegelin argued that the ideal is for human beings to hold these dimensions in a creative tension and balance; our temptation is to overemphasize one of the dimensions. Slavery, for example, was an oppressive overemphasis on the Great Chain of Being, and a false application of that idea to invent sub-races within the one human race. Collectivism, mob rioting, and lynching are examples of how the horizontal plane can be overemphasized and become violent. Individual selfhood can also be overemphasized and can become a vector for violence. Voegelin's thought provides an overall framework for understanding the order and disorder of the human soul and of society, and I have summarized and synthesized the insights of Voegelin, Kierkegaard, and Girard in my book The Trinitarian Self: The Key to the Puzzle of Violence.

Whenever I have taught the "Religion and Violence" course at Brite Divinity School, it has always been an in-class course, because the faculty at Brite have decided to focus on face-to-face instruction 
and not move in the direction of online courses. I have also taught courses often for the Master of Liberal Arts program at TCU, and that program offers a large number of online courses to students who are both local and geographically scattered. I have always offered "Religion and Violence" as an online course for the MLA program. This is a completely different set of students than those at the Divinity School. Many have some connection with the athletics program at TCU, either as athletes or graduate assistants. Some students work in various administrative roles at TCU; others are teachers, homemakers, business people, high school counselors, and so forth. In general, I cannot assume that these students have as much knowledge of religion as the divinity school students do. The students in the MLA program do have a strong level of interest and engagement in the topic of religion and violence, because it is a subject that one hears about so often in the news and reads about in history books.

My own teaching style focuses more on leading discussions of the assigned texts, rather than on giving lectures. This means that the two formats of instruction are fairly similar. The difference is that the online course relies on the students making posts on the reading material and then commenting on the posts of others; this is done asynchronously. The in-class course has a live discussion which is a bit less predictable in terms of where it will go. I have not tried to engage the online students synchronously because the scheduling and technical difficulties would be too much of a hassle to deal with. Another difference between the two formats is that TCU has a policy of limiting the enrollment of online courses to seventeen students. In my experience, that number always shrinks to about fourteen or fifteen due to students dropping during the semester. The in-class course at Brite, however, has a limit of thirty-five students, and usually has between twenty-five and thirty students enrolled. Inevitably, there will be some students who are more talkative and others who are mostly quiet. This creates a different dynamic because in the online format all of the students are forced to make the online posts and thus contribute to the discussion.

The last time I offered the course as an online MLA course, it was a compressed four-week summer session. That format also alters the dynamic, in that the focus really needs to be on the key books, and introducing several extra shorter readings is not feasible. In general, 
the MLA format assigns less reading than the Brite version because the students are not as capable of processing a large quantity and variety of materials.

Another element of the Brite course, in its most recent iteration, is that I was able to invite to class a guest speaker from the TCU Religion Department, Samuel Ross. He is a Muslim, and he was able to address very effectively some of the issues relating to Islam and terrorism. The students responded very well to that class session.

The online students make posts, usually two or three times a week; the in-class students usually have about five or six short papers that are spread throughout the semester. In general, the quantity of words written by the online students is greater, because we do not have in-class meeting time. Another key difference between the two formats is that the online students are forced to comment on all of the reading assignments (or suffer a grade penalty). I have no feasible way of forcing the in-class students to comment on all of the readings, and I'm sure that some of the students skip some of the readings.

I have been asked by Brite to offer "Religion and Violence" as a course for DMin students during the Fall semester of 2020. This will be a new format, because there is an online component during the whole semester, plus a one-week intensive in-class meeting during the month of October. I'm looking forward to this format and also to the cohort of students who will be more advanced and already in fulltime ministry of some sort. I will challenge them to apply what they are learning to homiletics and religious education.

After one of the iterations of the TCU online course, several of the students mentioned in their course feedback that they have learned much about violence, but they would like to know what to do about it. How can they contribute to making the world a less violent place? This coincided with an invitation from the MLA program to develop new courses that have not been offered before. I therefore developed a course called "Peacemaking in a Violent World" and have offered that once so far. One very intriguing dynamic in that course is that one of the students was actively training to become an officer in the US Army. As you can imagine, he brought a different perspective than most of the other students, who were civilians and who were more inclined to agree with arguments in the vicinity of pacifism. I was glad that he was in the course, although he referred to Stanley Hauerwas as "igno- 
rant" at one point. I pointed out to the student that Hauerwas can be called many things, but ignorant is not one of them. I know this from personal experience, having taking two courses from Hauerwas in the past.

\section{Bibliography on Violence and Religion}

Charles K. Bellinger, June 2019

*=more select list

Contagion: A Journal of Violence, Mimesis, and Culture. 1994-present. (Contains many articles on Girard)

Alison, James. The Joy of Being Wrong: Original Sin through Easter Eyes. New York: Crossroad, 1998.

*Alison, James, and Wolfgang Palaver, eds. The Palgrave Handbook of Mimetic Theory and Religion. New York: Palgrave Macmillan, 2017. Allport, Gordon W. The Nature of Prejudice. Cambridge, Mass.: AddisonWesley, 1954.

Appleby, R. Scott. The Ambivalence of the Sacred: Religion, Violence, and Reconciliation. Lanham, MD: Rowman \& Littlefield Publishers, 2000. Armstrong, Karen. Fields of Blood: Religion and the History of Violence. New York: Alfred A. Knopf, 2014.

*Bailie, Gil. Violence Unveiled: Humanity at the Crossroads. New York: Crossroad, 1995.

Becker, Ernest. Escape from Evil. New York: Free Press, 1975.

Bellinger, Charles K. The Genealogy of Violence: Reflections on Creation, Freedom, and Evil. New York: Oxford University Press, 2001.

*Bellinger, Charles K. The Trinitarian Self: The Key to the Puzzle of Violence. Eugene, Ore.: Pickwick Publications, 2008.

Carter, C. Allen. Kenneth Burke and the Scapegoat Process. Norman: University of Oklahoma Press, 1996.

*Cavanaugh, William T. The Myth of Religious Violence: Secular Ideology and the Roots of Modern Conflict. New York: Oxford University Press, 2009. Cone, James H. The Cross and the Lynching Tree. Maryknoll, N.Y.: Orbis Books, 2011. 
Cooper, Terry D. Dimensions of Evil: Contemporary Perspectives. Minneapolis: Fortress Press, 2007.

*Cowdell, Scott, ed. Does Religion Cause Violence?: Multidisciplinary Perspectives on Violence and Religion in the Modern World. New York: Bloomsbury Academic, 2018.

*Delsol, Chantal. The Unlearned Lessons of the Twentieth Century: An Essay on Late Modernity. Wilmington, Del.: ISI Books, 2006.

*Girard, René. I See Satan Fall Like Lightning. Maryknoll, N.Y.: Orbis Books, 2001.

*Girard, René. The Scapegoat. Baltimore: Johns Hopkins University Press, 1986.

Girard, René. Violence and the Sacred. Baltimore: Johns Hopkins University Press, 1977.

Girard, René. Deceit, Desire, and the Novel: Self and Other in Literary Structure. Baltimore: Johns Hopkins Press, 1965.

*Girard, René, Jean-Michel Oughourlian, and Guy Lefort. Things Hidden since the Foundation of the World. Stanford, Ca.: Stanford University Press, 1987.

Girard, René, Rocha, João Cezar de Castro, and Pierpaolo Antonello.

Evolution and Conversion:Dialogues on the Origins of Culture. New York: T \& T Clark, 2007.

*Girard, René, and James G. Williams. The Girard Reader. New York: Crossroad, 1996.

Hart, David Bentley. Atheist Delusions: The Christian Revolution and its Fashionable Enemies. New Haven Conn.: Yale University Press, 2009. *Heim, S. Mark. Saved from Sacrifice: A Theology of the Cross. Grand Rapids: Eerdmans, 2006.

Hunsinger, George. "The Politics of the Nonviolent God: Reflections on René Girard and Karl Barth.” Scottish Journal of Theology 51, no. 1 (1998): 61-85.

Juergensmeyer, Mark. Terror in the Mind of God. 4th ed. Berkeley: University of California Press, 2017.

"Juergensmeyer, Mark, Margo Kitts, and Michael K. Jerryson, eds. The Oxford Handbook of Religion and Violence. New York: Oxford University Press, 2013.

*Kierkegaard, Søren. The Sickness Unto Death: A Christian Psychological Exposition for Edification and Awakening. New York: Penguin Books, 1989. 
Lincoln, Bruce. Holy Terrors: Thinking about Religion After September 11. Chicago: University of Chicago Press, 2006.

McBride, James. "Capital Punishment as the Unconstitutional Establishment of Religion: A Girardian Reading of the Death Penalty." Journal of Church and State 37, no. 2 (1995): 263-287.

*Miller, Alice. For Your Own Good: Hidden Cruelty in Child-Rearing and the Roots of Violence. New York: Farrar, Straus, Giroux, 1983.

Murphy, Andrew R., ed. The Blackwell Companion to Religion and Violence. Malden, MA: Wiley-Blackwell, 2011.

*Palaver, Wolfgang. René Girard's Mimetic Theory. East Lansing: Michigan State University Press, 2013.

*Palaver, Wolfgang and Richard Schenk, eds. Mimetic Theory and World Religions. East Lansing: Michigan State University Press, 2018.

Peck, M. Scott. The Road Less Traveled. New York: Simon and Shuster, 1978.

Ricoeur, Paul. "Religion and Symbolic Violence." Contagion: Journal of Violence, Mimesis \& Culture 6 (1999): 1-11.

*Sacks, Jonathan. Not in God's Name: Confronting Religious Violence. New York: Schocken Books, 2015.

Schwager, Raymund. Must There Be Scapegoats?: Violence and Redemption in the Bible. San Francisco: Harper \& Row, 1987.

Selengut, Charles. Sacred Fury: Understanding Religious Violence. 3rd ed. Lanham: Rowman \& Littlefield, 2017.

Stein, Ruth. For Love of the Father: A Psychoanalytic Study of Religious Terrorism. Stanford, Calif.: Stanford University Press, 2010.

Steinmair-Pösel, Petra. "Original Sin, Grace, and Positive Mimesis." Contagion: Journal of Violence, Mimesis \& Culture 14, no. 1 (2007): 1-12. Swartley, Willard M., ed. Violence Renounced:RenéGirard, Biblical Studies, and Peacemaking. Telford, Pa.: Pandora Press, 2000.

Taylor, Charles. "Notes on the Sources of Violence: Perennial and Modern." In Beyond Violence: Religious Sources of Social Transformation in Judaism, Christianity, and Islam, edited by James L. Heft, 15-42. New York: Fordham University Press, 2004.

*Voegelin, Eric. Modernity without Restraint: The Political Religions, the New Science of Politics and Science, Politics, and Gnosticism. Columbia: University of Missouri Press, 2000.

*Weaver, Richard M. Ideas Have Consequences. Chicago: University of Chicago Press, 1948. 
Webb, Eugene. Philosophers of Consciousness: Polanyi, Lonergan, Voegelin, Ricoeur, Girard, Kierkegaard. Seattle: University of Washington Press, 1988.

Williams, James G. The Bible, Violence, and the Sacred: Liberation from the Myth of Sanctioned Violence. San Francisco: HarperSanFrancisco, 1992.

\section{MY HOME PAGE}

https://lib.tcu.edu/staff/bellinger/cbhome.htmhttps://lib.tcu.edu/staff/ bellinger/cbhome.htm

\section{BRITE COURSE}

https://lib.tcu.edu/staff/bellinger/rel-viol/rel-viol2019syllabus.htm https://lib.tcu.edu/staff/bellinger/rel-viol/rel-viol2019links.htm 